冷間加工硬化能に及ぼす低溫燒鈍効果”(第1部)銅及び銅合金

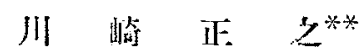

Masayuki Kawasaki: The Effect of Low-Temperature Annealing Upon the Work-Hardening Power. (Part I. Copper and Its Alloys). The intermediate 
low-temperature annealing was adopted for Copper and Brass at the break point of each workhardening curves and before or after that point. For the copper the low-temperature annealing brought about slight improving effect upon the subsequent work-hardening. However, for the Brass containing $35.2 \% \mathrm{Zn}$, there are two methods of improving effect for use, namely one that the slight softening due to the annealing increases the work-hardening power more strongly than one without such annealing and the other that the so-called "abnomal-hardening" due to annealing maintains the higher value of strength during a few subsequent stages of working. The for mer principle may be perhaps adopted for the case of $\mathrm{Ca}-\mathrm{Cd}$ alloy containing $1 \% \mathrm{Cd}$, alre ady reported, with almost the same significance, but this alloy displays more powerful effect than the brass because of the more strengthening ability of Cd-atom in the matrix of copper solid. solution than the $\mathrm{Zn}$-atom.

(Received June 27, 1949)

\section{I. 緒 害}

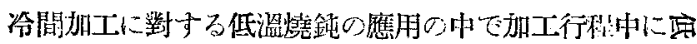

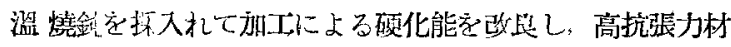

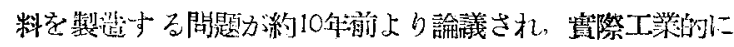

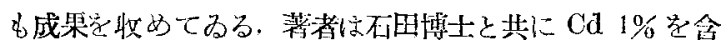

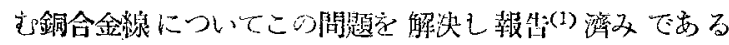

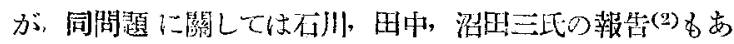
る.(但し加工硕化能に對寸る考察は拂われてない)，文，小

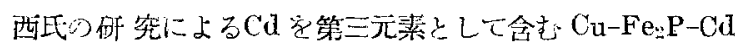

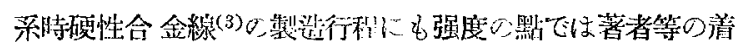
想を路入れても終局心成果を得ることか涼されている、

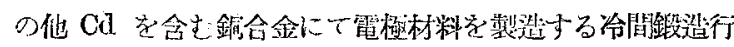

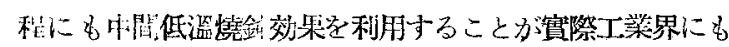

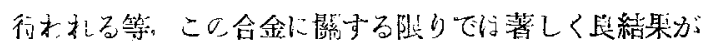

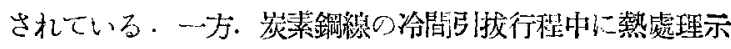

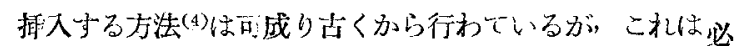
ザしる诸者等の閣題とする加工硬化能间上の目的のみでは ないと考えられる。更にアルミニウム整金金板に對しても

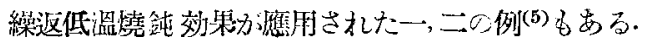

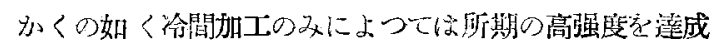

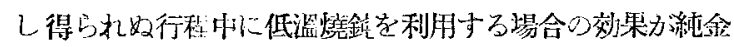
屬，均一固溶體、二相合金等に和いて果して如们なる擧動

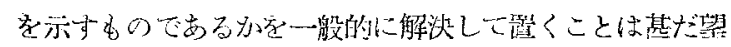

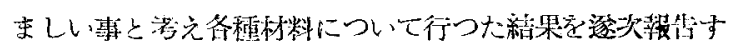

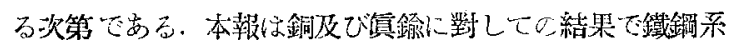
材料については次報に誏る。

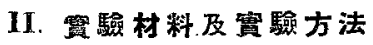

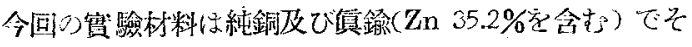

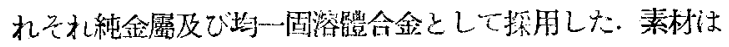

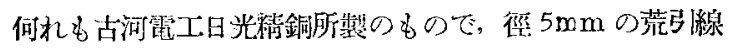

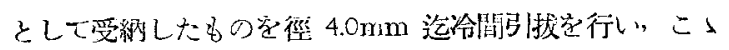

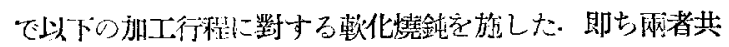

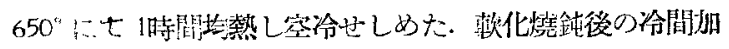

(1) 不田, 川㥓, 航空研究所啹告, No. 222 (1941), 293;

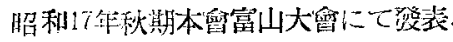

(2) 石川, 田中. 沼男, 本誌, 8(1944), 94.

(3) 小西, 占河鼠工特辑號, (昭和18年12月).

(4) A. Pomp, Stahl u. Eisen;45(1925), 777.

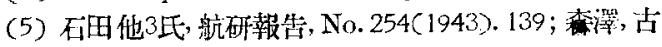
河電工. 金屬第唄(昭和18年7月), 26.

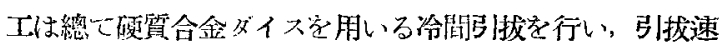

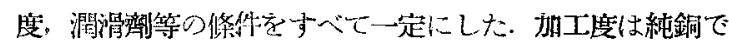

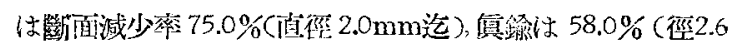
$\mathrm{mm}$ 迄)姿施したが，そる全行稆中のスケヂュールは次の

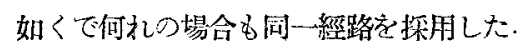

(㰩化筧鈍) $4.0 \mathrm{~mm} \rightarrow 3.6 \mathrm{~mm} \rightarrow 3.4 \mathrm{~mm} \rightarrow 3.2 \mathrm{~mm} \rightarrow 2.9 \mathrm{~mm} \rightarrow$ $2.6 \mathrm{~mm} \rightarrow 2.3 \mathrm{~mm} \rightarrow 2.0 \mathrm{~mm}($ 代上り).

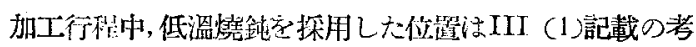
慮に基导网都共 $3.4 \mathrm{~mm}, 3.2 \mathrm{~mm}, 2.9 \mathrm{~mm}$ の中の何机か一段 階とし、純銅で活夫々 $255^{\circ}, 215^{\circ}, 155^{\circ}$ の溫度にて又筫鍮て

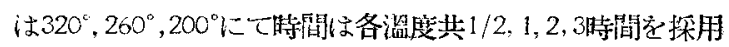
Lた.

以上の加工行程並に低溫燒鈍後の各段阹に物いて加工中 の線材より長さ $20 \mathrm{~cm}$ の試料学數本控取し總て引張試驗に

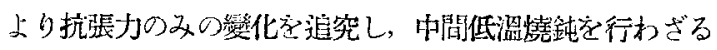

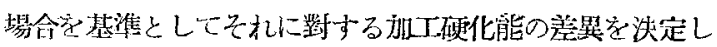
t:

\section{III. 留龭結果应にその考察}

(1) 冷間加工硬化曲線 冷間加工! - 作与硬化曲線入數例

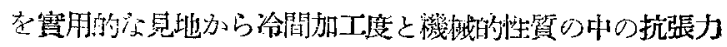

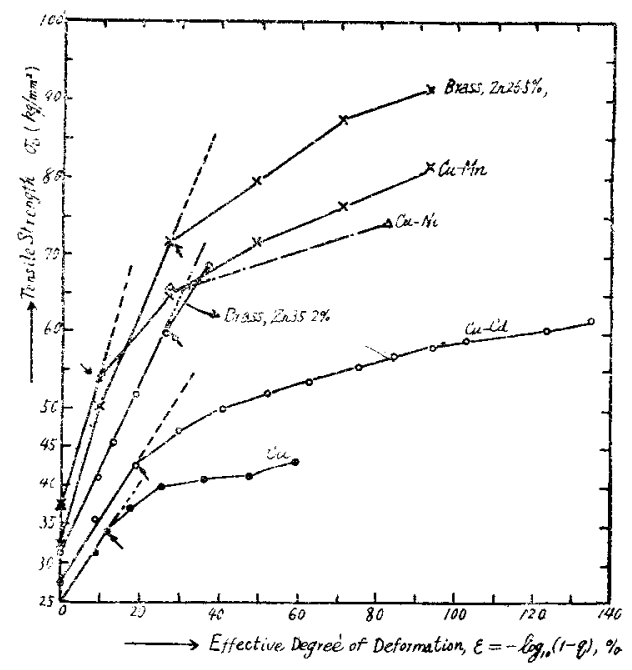

Fig. t The Work-hardening Curves of $\mathrm{Cu}$ and its Alloys.

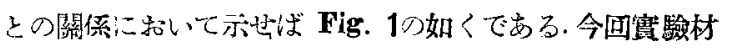

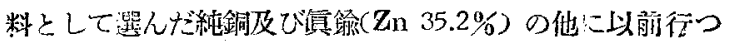


た2,3の銅合金に對する結果をむ併せて示してまる，加工 度は斷面減少率を $q$ とすれば $\varepsilon=-\ln (1-q)$ は所訣, 有效 變形量と稱せられるものでこれをFig.10横輠に取つてあ る(但し便宜上自然對數の代りに常用對數を用い且つをを \%にて表わ寸)。

各泩線的形狀はその根底に技いては立力晶系單結晶材料

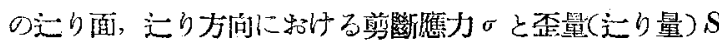

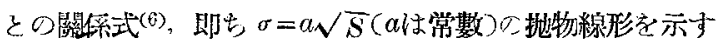

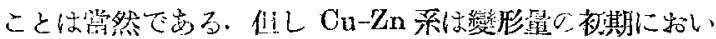

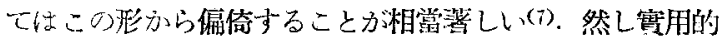

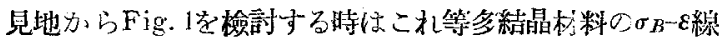

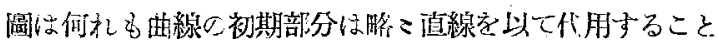
が出來る狀態である. 即もこの直線部分の保たれいる籍園て は一定の硬化能を示すことに没る。この一定度の硬化能の

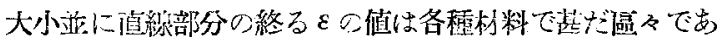
るが高抗張少材料の目的からは㨁接この网顷目の大るるこ と办留宗乙い。

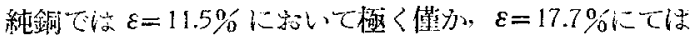

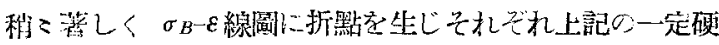
化能减少して行く，それ以後は $\varepsilon=47.6 \%$ 迄は上方一ら

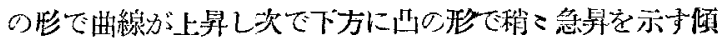
向*を取る．第一次の折點 $(\varepsilon=11.5 \%$ は極く微弱て加工條

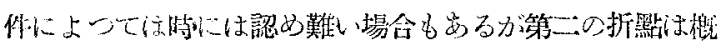
水一艘人認めら礼るから純銅の場合にはこれに注日寸る。

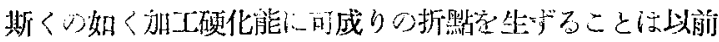

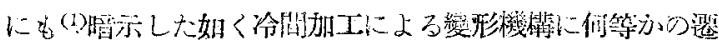

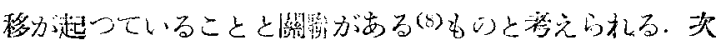

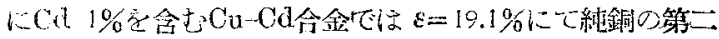

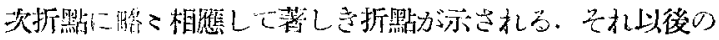

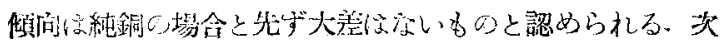

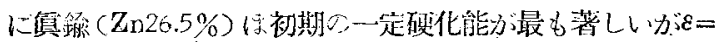

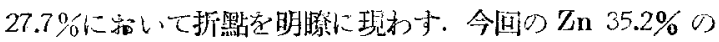

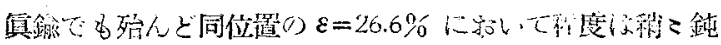

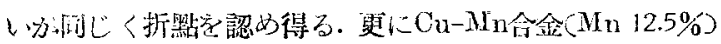

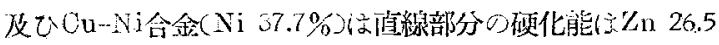

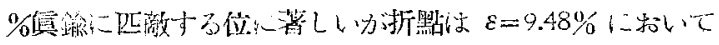

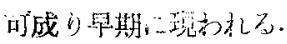

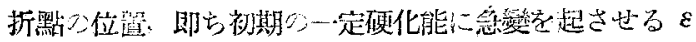

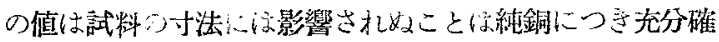

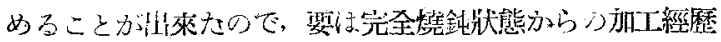
並に的工绦件のみに依存する少のであると装えられる。

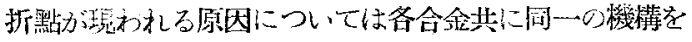
以つて說明し得るむのと思われるが，俩的にしても高抗張 力林料空得る笉にはこの折點学見かけ上名儿ど消失ぜし

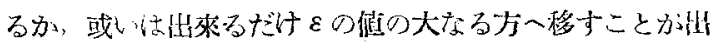

(6) G. I. Taylor, Proc. Boy. Soc, 145 (1934), 362.

(7) M. Masima u. G. Sachs; Z. Physik. 50(1928)161.

* この傾向は鐵銅系极料の場合法可成り萻しい(次 報に更に连心゙る)。

(8) M. Cook\&T. Richards, J. Tnst., of Met. 66 (1940). 1.
來ればよい摆で出る、この意味で折點に执いて一旦加工を

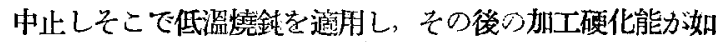

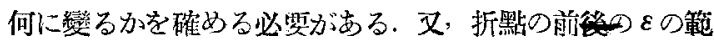

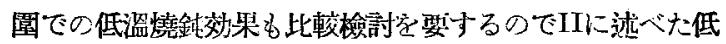

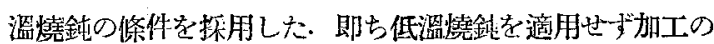

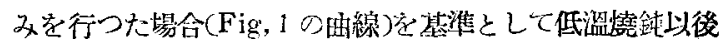
の硬化能進行狀況が如何に改變されるが㳔定するのであ る.

低溫等鈍々れ当體により加工後の抗張力力變化する樣子 は各合金共決して同じではない，即ら純銅では低温烇鈍の 溫度制溒では所謂「異常硬化現像」が抗張力では㱠んど認

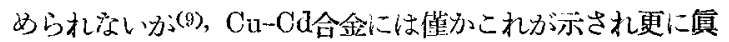
踭ではこの現象が頗る著明があることは既に啹告(10) した 所である. 從つて低湍繞鋌直後の加工硬化はこれ等の異れ

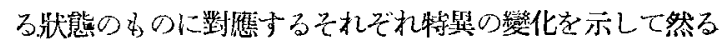

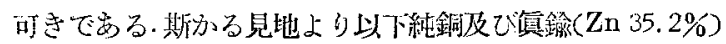

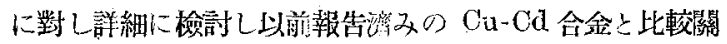
連せしめることとする。

(2) 練銅の低温㛙鈳後の加工硬化能 純銅の加工硬化曲 線に物ける $\varepsilon=11.5,17.7$ 及び 25.6\%の三呫江對し々れでれ

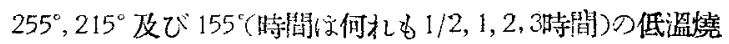
鈍を施し更に何れる $\varepsilon=59.8 \%$ 迄加工を續け，各段階に特

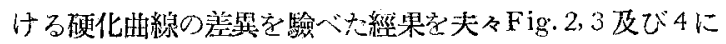

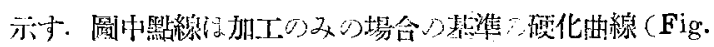
1 の中の曲線)である。

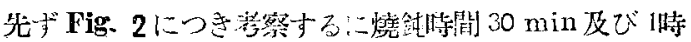

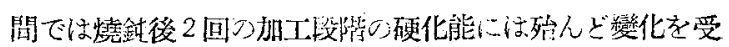

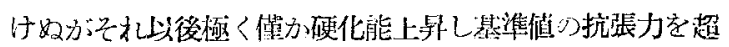

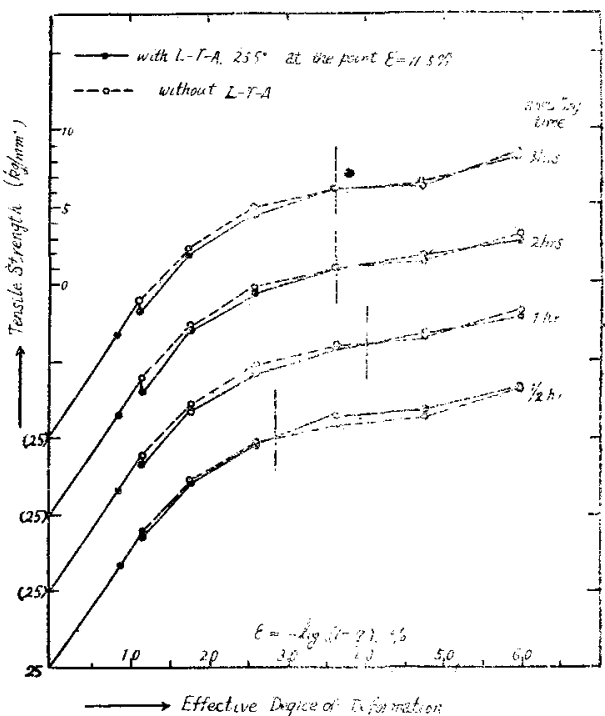

Fig. 2 Effect of L-T. - A. at $255^{\circ}$ for $1 / 2$ 3hrs upon the Work-hardening of Copper.

（9）純銅に於ても嚴密には類似の現象か特に高加工度

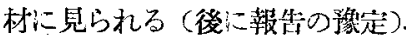

(10) 川䐀, 本誌 $14,2(1950), 36$ 


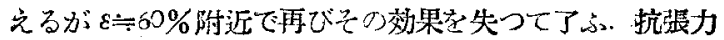

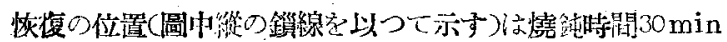

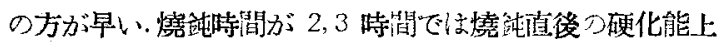

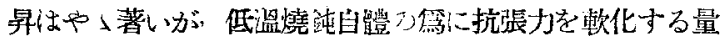

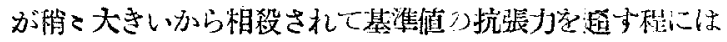

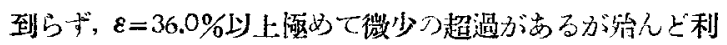
用偠値は問題になら妨之考之る。

以上の結果加ら純銅の注目した折點 $(\varepsilon=17.7 \%$ 以前の $\varepsilon$

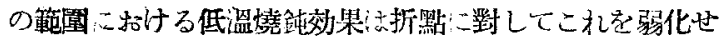
しめることは全く出來ず却つて僅か䖽化せしめる位でする

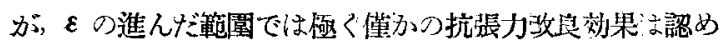
られる。

次にFig. 3 の場合では全體つ傾间として Fig.1の傾向

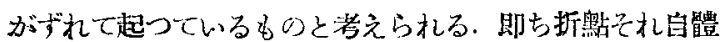

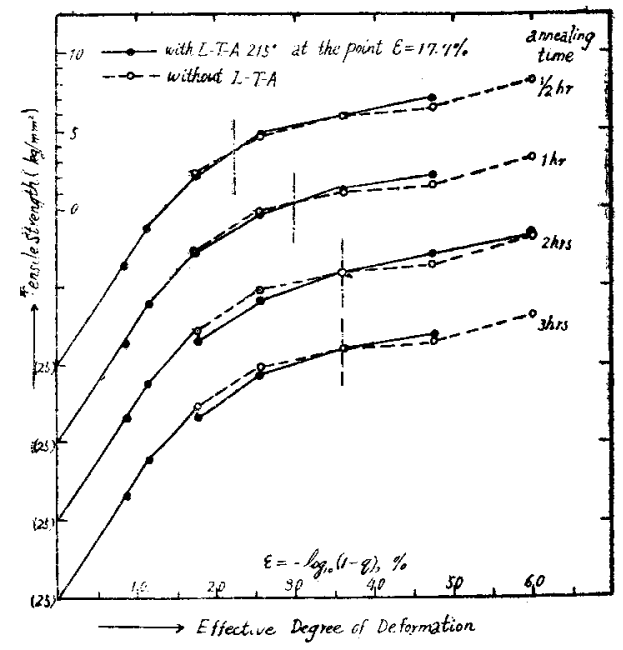

Fig. 3 Effect of I.-T-A. at $215^{\circ}$ for $1 / 2 \sim$ 3hrs upon the Work-hardening of Copper.

の程度は低湓燒钝により殖儿ど改㭙效果を示さず，それ

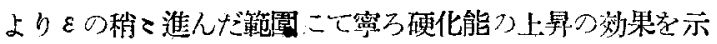

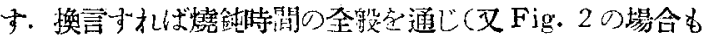

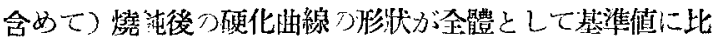

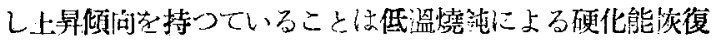

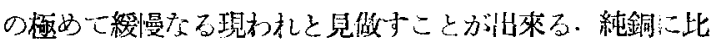

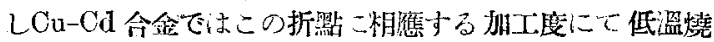

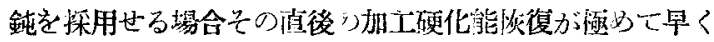

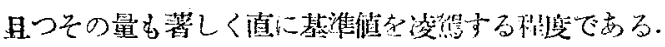

Fig. 4 の埸合も燒訰時間が1/2〜2時間では效果汒Fig.2

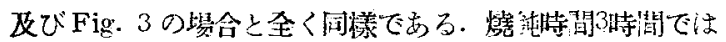

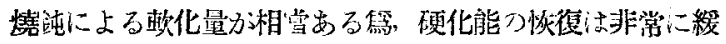

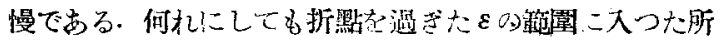

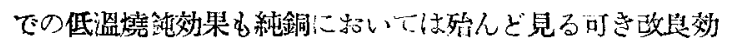
果を示さないと云える.

以上，純銅つ場合全般を通じて考察するに折點及びその

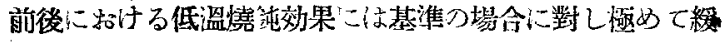
慢なる硬化能惔復を示ずことが認わられる、然し抗張力嘼 强つ目的つ霨にはその梅復効果安利朋することは多んど出
來ない程度である，但しこっで更に繰返低湓燒钝効果つ如

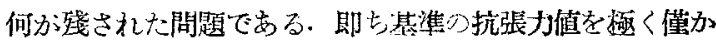

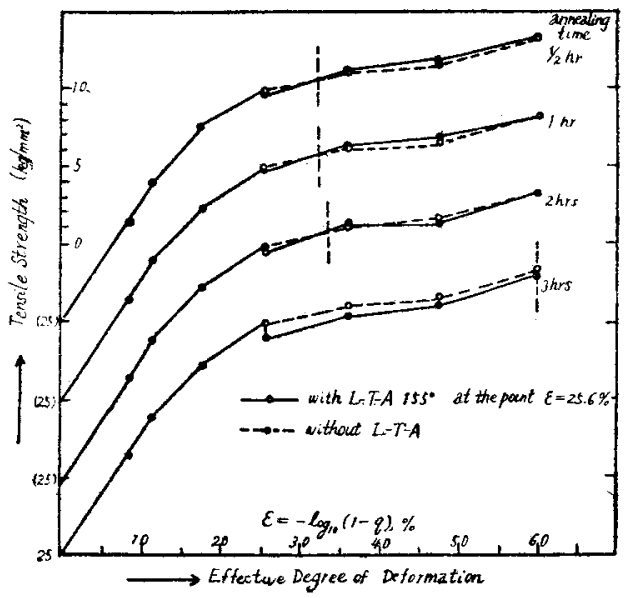

Fig. 4 Effect of L.-T.-A. at $155^{\circ} \mathrm{C}$ for $1 / 2 \sim$ Shrs apon the Work-hardening of Copper.

超えている加工段階(Fig. 2〜4各圖共 $\varepsilon=47.6 \%$ D繁儿注目

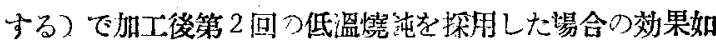

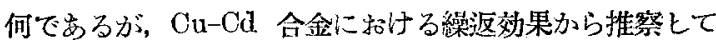

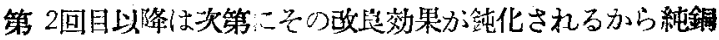

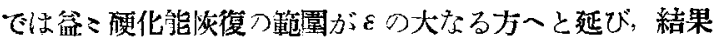
に扮いては抗張力變化には咍儿ど答與されぬことなると考 えられる。

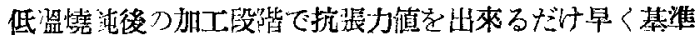

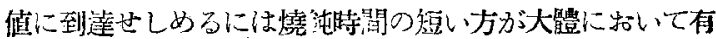

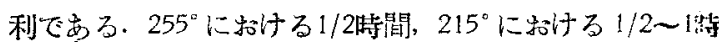

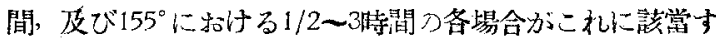

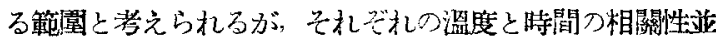

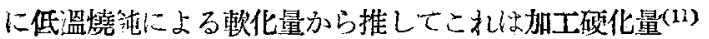
の恢笪䡈化つ程度である. 各溫度でそれ以上の時間の場合 には一部刀再結晶軟化を伴つているむのと考元れば，銅の

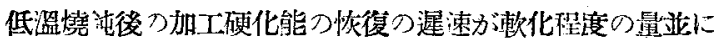

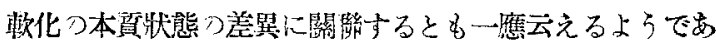

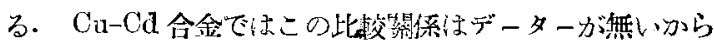
云之奴が，然し明らか：一部刀再結晶赖化を伴つ大狀態の 煊啳》加工硬化能为純銅几比儿極如て增大されることは純 金屬とこの合金つ地質の固溶體か强大であることとの根本 的差翼に其づくものと考之られる。

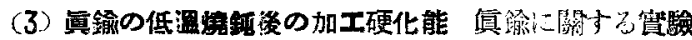

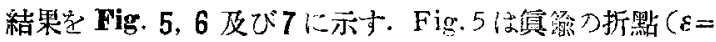

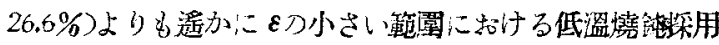

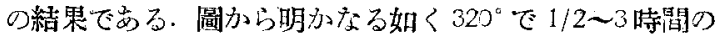
低溫㷪沌は既に異常硬化渦程(12) を濄ぎて或る程度再結晶

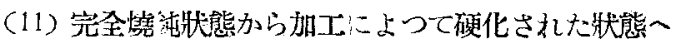
の變化望で，备加工段階に靬ける硬化能つことで は心な。

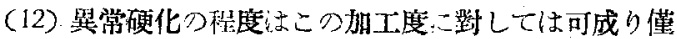
少庄中の子云六る。 
に上る傎化を示寸名のと考穴られる。然るに加工硬化能》 邨復は頗る緩骨で方り，前項(2)の終りで述べ太純銅とCu-

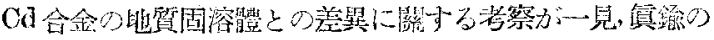

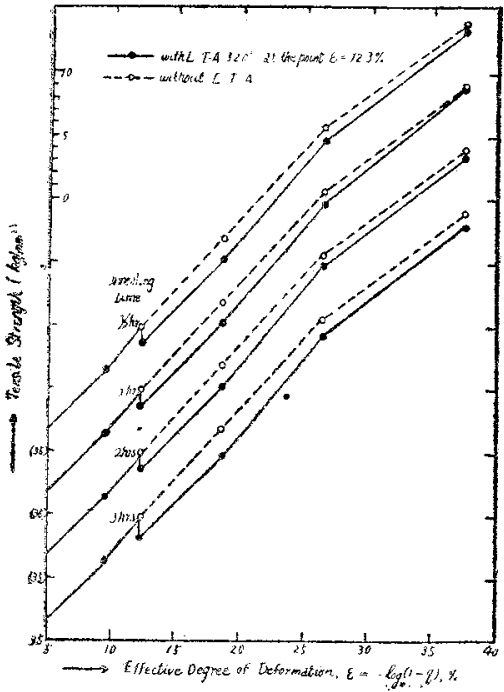

Fig. 5 Effect of I.-T.-A. at $320^{\circ}$ lor $1 / 2 \sim 3 h r s$. upon the Workhardning of Brass(Zn35.2\%).

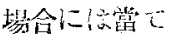
なまら欢よう に考它的る 为论の原因役 專以次事唡 によるものと 考完たい、即 b $\varepsilon=12.3 \%$

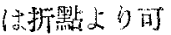

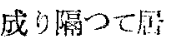
りその加工便 化量が折墨小 そ机比し は来ナ゙輕少て むる筑低温漈 鋩後口加工硬 化能向上に影 響与る程の柾 分布加充分心

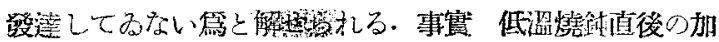

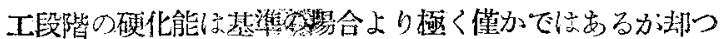
て低下している位いで，全體としては加工硬化能つ詣间が

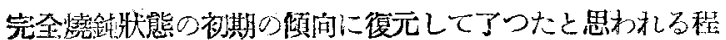
度で女る。或いは㨦言すれば低溫燒鈍に件ふこの程度の軟

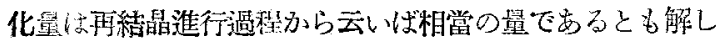
て上く，從つて上後の加工硬化力略ミ元に復して了らとも 見ら竌るのでる。

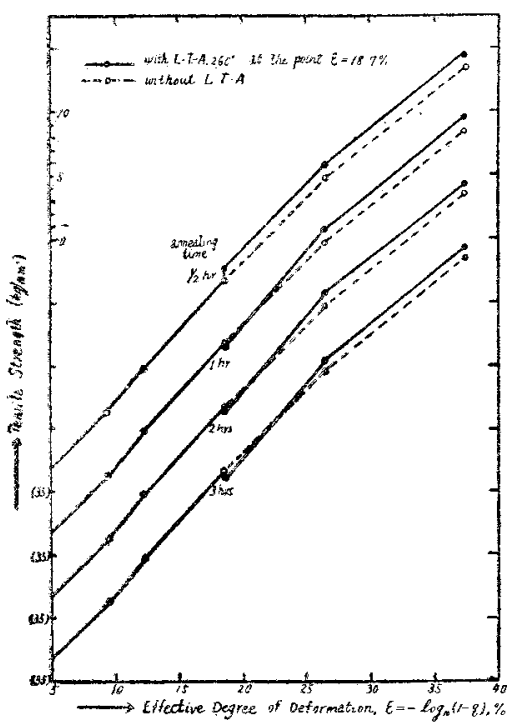

Fig.6 Effect of L.-T.-A. at $260^{\circ}$ for $1 / 2 \sim 3 \mathrm{hrs}$, upon the Workbardening of Brass (Zn35.2\%).
次仁Fig. 6 に特ける效果 く見るに $260^{\circ}$ で1/2〜3時間 の經過は恰度 $こ の$ 加工度 ( $\varepsilon=18.7 \%$ ) に對し巽常硬 化の最高の山 老過ざて降り

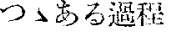
を示してい る. 而してそ の各狀態に和 ける加工硬化 能基準仁比 乙两成改影 効果を示して (る. 舊沙の)

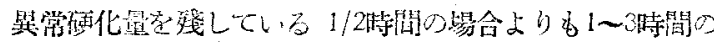

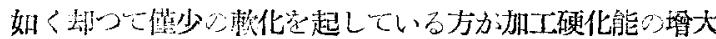

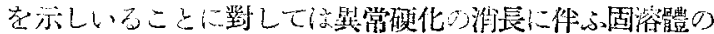

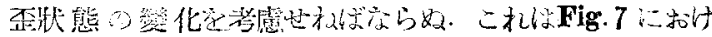

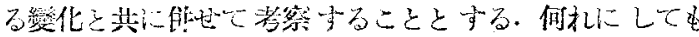

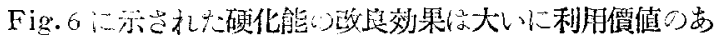

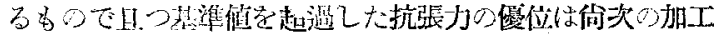

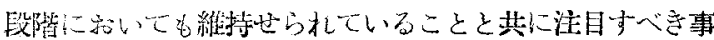
唡で安る。

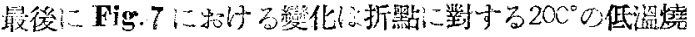

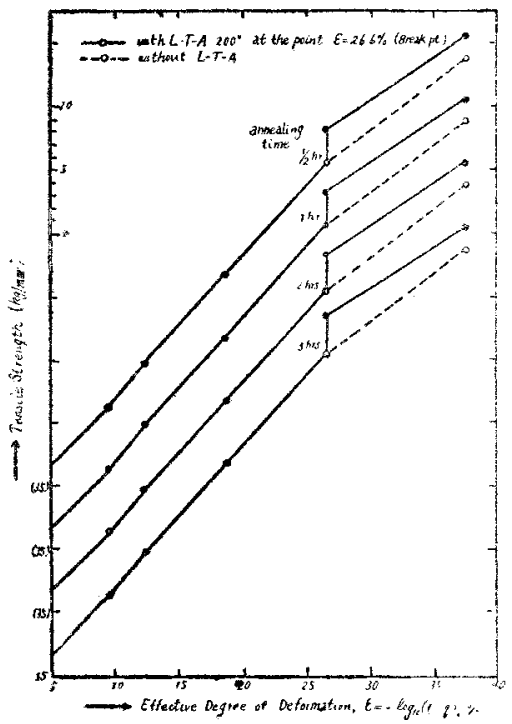

Fig. ? Effect of L. T.-A. at $200^{\circ}$ for 1/2 3hrs. upon the Workhardening of $\operatorname{Brass}(Z n$ 35.2\%).
鉷効果で市る が翼常骤化の 過程出潐行し つง焉る經過 を示し号の各 狀態加工硬 化能小基準の 埥合上り娍少 LTい. から見方洁上

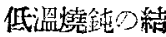
果, 硬化能刀 折點の程度少: 一㕌强化され たことにな ๖. Fig. 6 に 特ける效果女

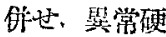
化量の堆淢に 件ら淔後の加工礝化能の變化を見るに暴常硬化の過程が最 高硬度つ山一と淮んでいる範圍では加工硬化能は基準より

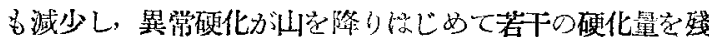

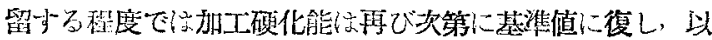

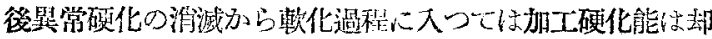

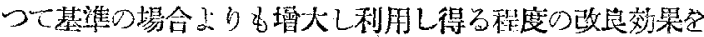

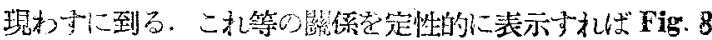

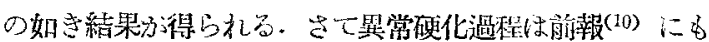
述べた如く，加工歪を受けている固溶體中心更に析出過程 以前の黑常枉の㡎生洼附加された歪硬化と考えることが出

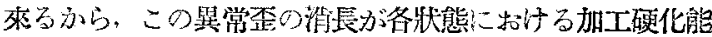

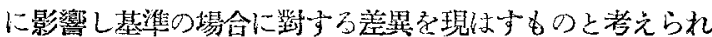

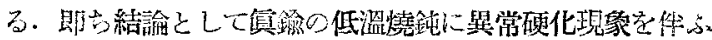

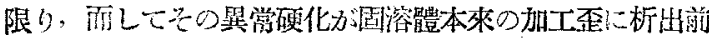

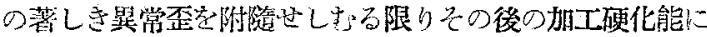

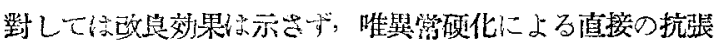

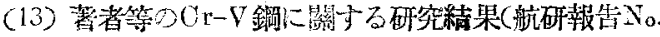

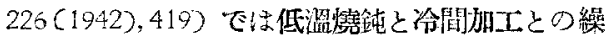

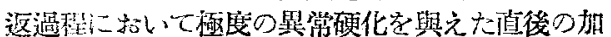
工硬化は却つて加工软化となつて現れるこるが硬

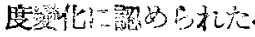


力上舁のみを利用することげけが可能でする。

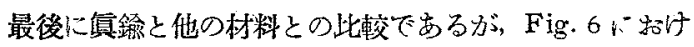

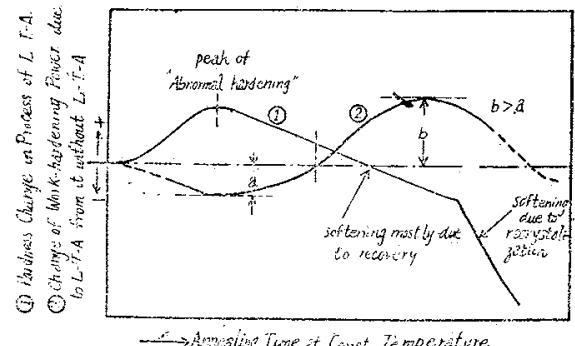

Fig. 8 Qualitative Representation of Relation between the Process of L.-T.-A. and the Change of Work-hardening Power due to L.-T.-A. from it without L.-T.-A. (Brass containing $35.2 \% \mathrm{Zn}$ )

る1 3㭙间の时線と純銅つFig.2に特江る各曲線との此校

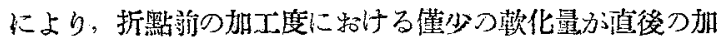
工硬化能洃復の速さに對し與之る影響刀點で㫜らか心純銅

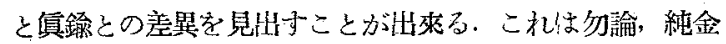

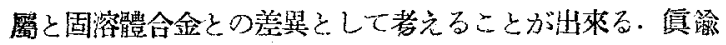

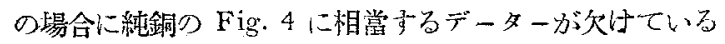

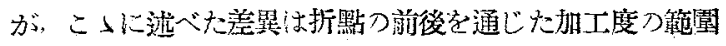

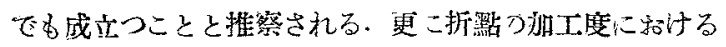

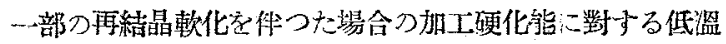

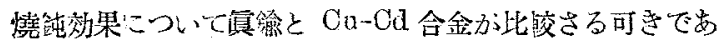
るが前者心甜ける゙゙ーター不足の篤推論以上には出始が

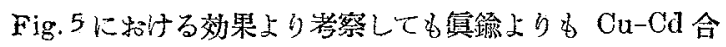
金の方がその照では强、致食效果を示与るのと思われる。 これは銅合金固溶體として Cd 1 原子が與える固溶體本來 の强化作用の方がZn 1 原子よりも大ですることに結論と ‘て歸着すると考えられる.この强化作用力大小心雨溶質 原子 1 原子\%賞りに比茭した固溶體つ初期刀一定加工便化

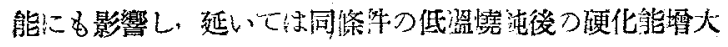
の差異にも効くものと思机るからである. 唯實際間題と

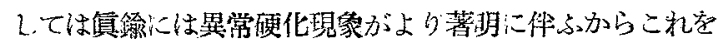

併せ七有用に利用することか心出來る，殊、こ繰返低溫燒纯效 果つ方洗を適用する場合には经々その效用があるものと期 待泏來る。

\section{W. 總括及び結論}

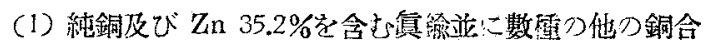
金つ冷間扣工便化曲線を實用的な目的加ら檢討し，曲線に

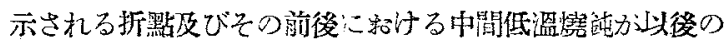

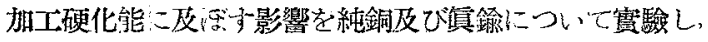
併せて主として從來つ $\mathrm{Cu}-\mathrm{Cd}$ 合金つ結果々比洨考察した。

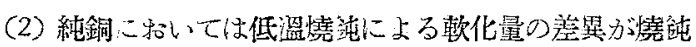

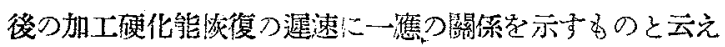

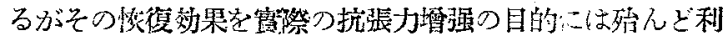

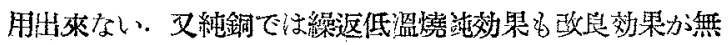
いるのと考えられる. 純銅と $\mathrm{Cu}-\mathrm{Cd}$ 合金とに挌ける比較

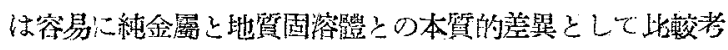
察することが出來る。

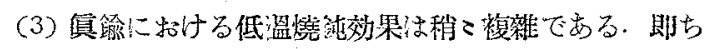

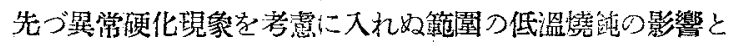
しては，勿諭純銅二對する $\mathrm{Cu}-\mathrm{Cd}$ 合金つ比較法察力洞樣

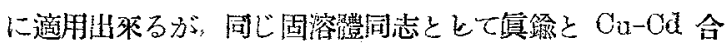
金つ地質との比賋では後者つ方が扣工硬化能樰大刀點では 上り强い効果を示士もので，これは結局つ所，兩原子1原 子\%當りに此较した場合つ兩者の固溶體本來つ强化作用の 美二そつ考察を求め就なら奴と考它る。

(4) 熼常硬化現象つ過程にある狀態の加工硬化能は，大

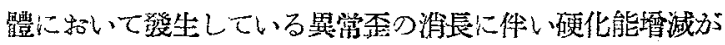

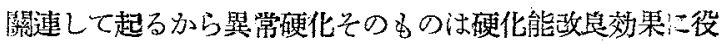
立た炕ととなる.唯翼常硬化力結果直接二抗張力が高め られるからこれを利用することは出來る。殊こ(3)と相閣

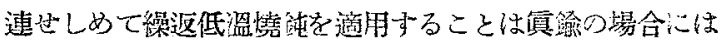
有利と考える.

終りに今回方管驗付料調製に關し種々の御好意と御便宜 とを與へられた古河電工田中诰氏前に東大理工研舜田㸚授 に厚く謝意を表する。侗本研究は一部交部省自然科學研究 費の補助により行はれた。 